University at Albany, State University of New York

Scholars Archive

$1-2012$

\title{
The Floracrats: State-Sponsored Science and the Failure of the Enlightenment in Indonesia
}

Michitake Aso

University at Albany, State University of New York, maso@albany.edu

Follow this and additional works at: https://scholarsarchive.library.albany.edu/history_fac_scholar

Part of the History Commons

\section{Recommended Citation}

Aso, Michitake, "The Floracrats: State-Sponsored Science and the Failure of the Enlightenment in Indonesia" (2012). History Faculty Scholarship. 26.

https://scholarsarchive.library.albany.edu/history_fac_scholar/26

This Book Review is brought to you for free and open access by the History at Scholars Archive. It has been accepted for inclusion in History Faculty Scholarship by an authorized administrator of Scholars Archive. For more information, please contact scholarsarchive@albany.edu. 


\section{The Floracrats: State-Sponsored Science and the Failure of the Enlightenment in Indonesia.}

By Andrew Goss. Madison: University of Wisconsin Press, 2011.

Pp. xii+256. \$26.95.

Do you know of any Indonesian natural scientists? Most of us, Andrew Goss suggests, would have difficulty coming up with more than a couple of names. In this book, Goss offers some reasons why this might be so. He argues that "the failure of the Enlightenment . . . is the key to understanding the history of science and the politics of knowledge in modern Indonesia" (p. ix). Goss supports his thesis by examining three formative periods in the relationship between state and civil society: the 1830s and 1840s, when a few Europeans tried to incorporate scientific inquiry into a broadly defined natural history, with the product of this union, they hoped, being an integral part of an emergent civil society; the decades around 1900, when Melchior Treub, an experimental biologist, equipped the Buitenzorg Botanical Gardens with a laboratory that became famous among the European scientific community as a place to study tropical nature; and the 1950s and 1960s, when scientists of the newly established Republic of Indonesia considered how to craft a distinctly Indonesian biology. At these moments it seemed possible to enlarge public support for science. In each case, however, knowledge production was effectively co-opted by states suspicious of sources of legitimacy outside of their control.

Strictly speaking, only chapters 2, 4, and 6 address technology directly. For example, chapter 2, "Quinine Science," analyzes the quinine gardens directed by Franz Junghuhn, a former military doctor. These gardens were designed to reflect the "glory and power" (p. 34) of his patron. It shows that whereas Junghuhn knew how to court political power-he named a species of cinchona after his patron-the ex-physician could not get this species to 
JANUARY

2012

VOL. 53

become a commercial source of quinine for anti-malaria drugs. Goss's analysis of an 1863 Dutch parliamentary debate about quinine science shows nicely how political and economic liberalism in the Netherlands could affect science in the Dutch East Indies. After this debate and Junghuhn's death in 1864, quinine science was placed under greater bureaucratic oversight and successful research eventually produced cinchona trees with high quinine yields.

Yet there is much else of interest to historians of technology throughout this book, starting with the title. Playing on the well-known concept of technocrats, Goss defines floracrats as "naturalists working as colonial officials on state projects" (p. 9). He argues that the word "technocrat" does not accurately describe the naturalists and biologists he considers, because colonial and postcolonial "state policies were not about creating technical solutions per se but about generating systems that they could effectively administer" (p. 47). This is a subtle distinction but one that is consistent with Goss's evaluation of the balance of power between government officials and scientists in Indonesia.

Two of the most significant findings of Floracrats come in its analysis, beginning in chapter 5, of the role of biology and biologists in decolonization. First, Goss convincingly demonstrates that postcolonial approaches to science in Indonesia have roots in the colonial period. Goss argues that especially after 1959 Indonesian biologists carried out "desk science," which "linked pure knowledge to national development" (p. 164). While this practice failed to produce "world-class science," it ensured state support for biological research that fulfilled national needs. A prime example was Flora Malesiana, a project aimed at synthesizing knowledge about Indonesian plants. Second, Goss holds that only science and not scientists played a significant role in the Indonesian revolution of the late 1940s. Ming-cheng Lo's Doctors within Borders (2002), a study of Taiwanese medical doctors, suggests differences with regard to the role of disciplines in anticolonial movements.

My main criticism of this otherwise useful book concerns the author's use of the concept of civil society, a notoriously slippery term. Goss's discussion of civil society is well integrated into the historical narrative, but he gives the term more explanatory power than it perhaps merits. An overly tight linkage among civil society, Enlightenment, and science places too much blame for a failure of Enlightenment science, or the "dispassionate, free, and useful inquiry into the workings of nature" (p. ix), on a weak civil society. Clarifying relationships among these concepts would help qualify the judgment that government employment stifled the "sheer, creative potential of the professional scientists" and "has led to the failure of Indonesian science" (p. 11). Goss is at his best when he thoughtfully balances the opportunities with the perils of state-sponsored science.

Goss presents a convincing case for a failure of European-style Enlight- 
enment science in Indonesia, but why this happened and what it meant remain open to debate. Overall, Floracrats is a strong book and an original contribution to the global history of colonialism, biology, and science and society.

\section{MITCH ASO}

Mitch Aso received his Ph.D. in the history of science from the University of WisconsinMadison, and is currently a postdoctoral fellow at the Asia Research Institute, National University of Singapore. 